\title{
A TUTELA JURÍDICA DO CONSUMIDOR DIANTE DO ATRASO DO INCORPORADOR IMOBILIÁRIO
}

\author{
THE CONSUMER'S LEGAL PROTECTION IN FACE OF REAL ESTATE \\ DEVELOPER'S DELAY
}

Fabricio Germano Alves*

Thiago de Lucena Motta**

\begin{abstract}
RESUMO: o presente artigo trata das consequências jurídicas do atraso do incorporador em entregar o edifício em uma incorporação imobiliária, analisando as opções colocadas pelo ordenamento jurídico à disposição do consumidor adquirente lesado pela mora. O contrato de aquisição de unidade autônoma em incorporação imobiliária envolve, em regra, fornecedor e consumidor, o que atrai a incidência do regime protetivo instituído pelo Código de Defesa do Consumidor. A partir de análise da normatização pertinente, de bibliografia especializada e decisões de tribunais, o objetivo do presente trabalho é demonstrar que a lógica que deve orientar os casos de atraso é a responsabilização do incorporador pelos danos de qualquer ordem causados ao consumidor, garantindo-se a este autonomia para prosseguir no contrato ou proceder à resolução do mesmo.
\end{abstract}

PALAVRAS-CHAVE: Atraso na entrega do edifício. Incorporação imobiliária. Proteção do consumidor.

ABSTRACT: This article deals with the legal consequences of the contractor's delay in delivering the building in a real estate development contract, analyzing the options legally provided to the consumer affected by the delay. The contract of acquisition of an autonomous unit in a real estate development involves, as a rule, supplier and consumer, which attracts the incidence of the protective system established by the Consumer Defense Code. By analyzing the existing regulation, the specialized academic production and courts' precedents, the objective of this work is to show that the logic that should guide such cases of delay is the liability of the contractor in case of harms of any order inflicted upon the consumer, assuring to the latter the autonomy to remain in the contract or to withdraw from it.

KEYWORDS: Consumer protection. Delay in the delivery of the building. Real estate development.

\footnotetext{
* Especialista em Direito do Consumidor e Relações de Consumo pela Universidade Potiguar (UNP). Mestre em Direito pela Universidade Federal do Rio Grande do Norte. Mestre e Doutorando em Sociedad Democrática, Estado y Derecho pela Universidad del País Vasco/Euskal Herriko Unibertsitatea (UPV/EHU) - Espanha. Professor de Direito das Relações de Consumo na Universidade Federal do Rio Grande do Norte (UFRN). Email: fabriciogermano@hotmail.co.uk

${ }^{* *}$ Aluno do curso de graduação em Direito da Universidade Federal do Rio Grande do Norte. Aluno Erasmus da Faculdade de Direito da Universidade do Porto no semestre acadêmico de 2013/2014. E-mail: thiago@Imlnatal.com.br

Revista da Faculdade de Direito - UFPR, Curitiba, vol. 60, n. 1, jan./abr. 2015, p. 163-192.
} 


\section{INTRODUÇÃO}

O mercado imobiliário brasileiro alcançou grande desenvolvimento nos últimos anos, aumentando significamente todo o tráfego jurídico relativo à construção, comercialização e aquisição de imóveis. O complexo negócio de incorporação imobiliária, disciplinado pela Lei Federal 4.591/64, é certamente um dos mais importantes meios de instrumentalização dessas relações. Estimulado pela progressiva facilidade na concessão de crédito, este fenômeno tornou possível (ou pelo menos mais fácil) à grande parte da população o acesso ao imóvel próprio. Entretanto, não poucos problemas intensificaram-se a partir dessa nova realidade social; o atraso na construção e posterior entrega do bem adquirido é um dos principais transtornos que se manifestam nesse cenário.

O cotidiano forense tem demonstrado que tal situação enseja a propositura de uma multiplicidade de ações - com conteúdos bastante semelhantes - por parte de adquirentes insatisfeitos com a demora na execução do contrato. O Poder Judiciário tem sido provocado a decidir repetidamente sobre as mesmas questões, e não raro o faz de formas diferentes. A divergência do conteúdo dos julgados quanto à tutela do consumidor prejudicado nessas situações é significante e recai sobre praticamente todos os aspectos da matéria - de maneira que muitos adquirentes não têm seus direitos protegidos adequadamente.

Torna-se necessário, assim, sistematizar as consequências jurídicas do atraso na entrega do imóvel na incorporação imobiliária, harmonizando os interesses dos atores envolvidos sem descurar da tutela efetiva dos direitos dos adquirentes. A proteção destes exige que se empreenda um diálogo entre os diplomas legislativos que disciplinam o tema, aplicando-se o Código de Defesa do Consumidor (CDC), a Lei Federal 4.591/64 e, de forma suplementar, o Código Civil. Tendo como referencial a incidência conjunta desses regimes legais, serão analisados criticamente diversos entendimentos jurisprudenciais e doutrinários sobre o tema, e posteriormente se buscará apresentar propostas de soluções para os poblemas apontados. Para tanto, o método utilizado foi o estudo da produção acadêmica nacional e internacional especializada na questão, da disciplina normativa (com enfoque nos diplomas legais supracitados) e dos entendimentos seguidos pelos tribunais, inclusive pelo Superior Tribunal de Justiça (STJ).

Primeiramente, falar-se-á sobre os aspectos gerais do negócio jurídico de incorporação imobiliária, para em seguida perquirir a incidência da Lei Federal 4.591/64, do CDC e do Código Civil em seu âmbito. Posteriormente, serão examinados os direitos do consumidor à resolução do contrato em casos de atraso do incorporador (com restituição total 
dos valores pagos) e à indenização pelos prejuízos sofridos. Analisar-se-ão, também, os parâmetros de validade da cláusula que concede prazo de tolerância ao incorporador e, por fim, as consequências do atraso sobre a correção monetária do saldo devedor.

\section{CARACTERIZAÇÃO DO NEGÓCIO JURÍDICO DE INCORPORAÇÃO IMOBILIÁRIA}

A incorporação imobiliária, disciplinada pela Lei Federal 4.591/64, é um dos meios mais utilizados para viabilizar a aquisição de imóveis (não só, mas principalmente) para fins habitacionais. Trata-se de negócio jurídico complexo, envolvendo, em geral, múltiplas partes. As figuras do incorporador e do adquirente sempre se fazem presentes, sendo possível a intervenção, também, de instituições financeiras e de um construtor. Destarte, a incorporação tende a veicular-se por meio de mais de um instrumento contratual.

O parágrafo único do artigo 28 da Lei Federal 4.591/64 apresenta uma definição legal da incorporação ${ }^{1}$, elencando como um de seus elementos principais a promoção da construção de edifícios compostos por unidades autônomas voltadas para a alienação. O negócio consiste, portanto, em avença em que uma das partes - o incorporador - obriga-se a construir (com seus próprios esforços ou por meio da contratação de um construtor externo) edificação imobiliária formada por frações independentes, em condomínio, com a intenção de entregá-las aos adquirentes quando da conclusão das obras (CHALHUB, 2010, p. 151). O objeto da incorporação, portanto, será sempre atividade de construção orientada à alienação.

Os mesmos elementos típicos do referido negócio podem ser encontrados em ordenamentos jurídicos estrangeiros. No direito francês, por exemplo, o artigo 1.601.1 do Code civil descreve o contrato de vente d'immeuble à construire (venda de imóvel a ser construído) como aquele em que "o vendedor se obriga a edificar um imóvel dentro de um prazo determinado no contrato" ${ }^{2}$. A propriedade da fração ideal do bem pode ser transferida ao adquirente quando da conclusão das obras e pagamento do preço, ou já no momento da celebração do contrato (sendo que, neste caso, o incorporador conserva os poderes de proprietário até a finalização da construção) $)^{3}$. É essencial, de toda forma, a configuração da venda de coisa futura, cuja construção caberá ao incorporador e deverá ser realizada em um

\footnotetext{
${ }^{1}$ Art. 28. Parágrafo único: Para efeito desta Lei, considera-se incorporação imobiliária a atividade exercida com o intuito de promover e realizar a construção, para alienação total ou parcial, de edificações compostas de unidades autônomas.

2 "La vente d'immeubles à construire est celle par laquelle le vendeur s'oblige à édifier un immeuble dans un délai déterminé par le contrat", no idioma original.

${ }^{3}$ Arts. 1.601 .2 e 1.601 .3 do Code civil, respectivamente.

Revista da Faculdade de Direito - UFPR, Curitiba, vol. 60, n. 1, jan./abr. 2015, p. 163-192.
} 
prazo específico (BERGEL, 2010, p. 19). O direito belga tipificou negócio em todo semelhante, mas destinado especificamente à habitação do adquirente (WEYTS, 2002, p. 285); trata-se da vente d'un logement à construire (venda de habitação a ser construída).

Na Alemanha, a Makler- und Bauträgerverordnung (ou "regulação dos corretores e incorporadores") aplica-se à empresa que constrói e vende unidades imobiliárias, de forma semelhante à do incorporador brasileiro - com a diferença de que este último não precisa ser o construtor da obra. A referida lei impõe uma série de deveres ao incorporador, como a securitização dos valores a serem pagos pelos adquirentes $(\$ 2.1)$ e a regularidade notarial da incorporação (\$3.1), de modo a não prejudicá-los em caso de impossibilidade de continuação da construção (GRZIWOTZ, 2014, p. 433). O dever de informação também recebe atenção, cabendo ao incorporador transmitir ao adquirente uma série de dados e advertências quanto à incorporação $(\S \S 10.2$ e 11$)$. O direito austríaco, seguindo a mesma tendência, disciplina o Bauträgervertrag (contrato de incorporação) em Lei Federal (Bauträgervertragsgesetz), estabelecendo um regime bastante protetivo para o adquirente.

O sistema brasileiro difere dos acima elencados em múltiplos aspectos, especialmente em detalhes na caracterização do contrato e de seus sujeitos. Orienta-se, contudo, pelo mesmo valor de tutela do adquirente e de diminuição da desigualdade entre ele e o incorporador, por meio da imposição legal de deveres e limitações a este último começando pela definição de quem está autorizado a sê-lo.

O artigo 29 da Lei Federal 4.591/64 estabelece que o incorporador pode ser pessoa física ou jurídica, indistintamente; basta que se vincule à construção do edifício e à alienação de suas frações ideais. $\mathrm{O}$ artigo 31 da mesma Lei, todavia, estabelece que somente poderá ser incorporador o proprietário do terreno (ou o promitente comprador e seu cessionário, já que estes possuem direito à aquisição da propriedade) em que se realizará a construção, o próprio construtor e o corretor de imóveis.

O incorporador assume o compromisso de realizar a edificação do imóvel, e, uma vez realizados os procedimentos legais de registro e detalhamento da incorporação ${ }^{4}$, pode alienar as frações ideais do terreno - vale dizer, os quinhões correspondentes às unidades autônomas a serem construídas. Sua principal obrigação é, assim, direcionar os recursos de

\footnotetext{
4 A Lei Federal 4.591/64 prevê diversos ritos necessários ao regular desenvolvimento da incorporação, geralmente com o intuito de fornecer maior segurança aos adquirentes quanto à propriedade imóvel almejada. É o caso, por exemplo, do memorial de incorporação, instrumento contido no artigo 32 da referida lei e que consiste na caracterização dos aspectos principais da edificação. A constituição de patrimônio de afetação, positivada nos artigos 31-A a 31-F da mesma lei, também se insere no âmbito das garantias concedidas ao adquirente. Esses deveres, aliás, tem o mesmo escopo daqueles contidos nos $\S \S 3.1$ e 2.1, respectivamente, da Makler- und Bauträgerverordnung alemã.

Revista da Faculdade de Direito - UFPR, Curitiba, vol. 60, n. 1, jan./abr. 2015, p. 163-192.
} 
sua atividade empresarial para realizar a construção do edifício e a alienação de suas frações àqueles que estejam interessados em adquiri-las (PEREIRA, 2014, p. 216 et seq.).

É possível que o incorporador e o construtor sejam pessoas distintas; afinal, a função do primeiro é providenciar a edificação e a alienação das frações ideais, não se exigindo que o faça por meio de seus próprios recursos e esforços (CHALHUB, 2010, p. 153). Nessa situação, o incorporador continuará responsável integralmente pelo cumprimento da obrigação de construir, ainda que não a realize diretamente - a exemplo do que ocorre com a promessa de fato de terceiro prevista no artigo 439 do Código Civil ${ }^{5}$.

$\mathrm{O}$ adquirente, por outro lado, contrata com o incorporador a entrega de sua unidade em determinado prazo, mediante o pagamento de uma contraprestação pecuniária fixa, reajustável ou apenas estimada no instrumento contratual, conforme o regime de incorporação estabelecido $^{6}$. É possível que o adquirente se utilize de recursos fornecidos por instituição financeira como meio para realizar o cumprimento de suas obrigações, existindo diversas espécies de contrato para tanto. Em tais casos, o adquirente vincula-se a pagar à instituição o valor mutuado, com os respectivos acréscimos legais e contratuais ${ }^{7}$.

A incorporação é negócio formal, cuja validade depende de diversos requisitos previstos na Lei Federal 4.591/64. É necessário, primeiramente, registrar o memorial de incorporação (artigo 32), que conterá o detalhamento da obra e a individualização e descrição de cada fração ideal. O contrato de alienação da unidade também deve ser registrado (artigo $35, \S 4^{\circ}$ ) para que adquira publicidade e eficácia real, cabendo ao incorporador outorgar a escritura de compra e venda com todos os requisitos legais que possibilitem seu registro. Não o fazendo, praticará contravenção penal tipificada no artigo 66, inciso III, da mesma lei.

O contrato é, além disso, consensual, pois se completa com a manifestação de vontade das partes quanto aos elementos essenciais da avença (WIELE, 2001, p. 25); bilateral (ou multilateral) e oneroso, já que implica obrigações para ambas as partes, que objetivam o auferimento de vantagens próprias; sinalagmático, porque essas obrigações guardam entre si

\footnotetext{
${ }^{5}$ Art. 439. Aquele que tiver prometido fato de terceiro responderá por perdas e danos, quando este o não executar.

${ }^{6}$ Em termos gerais, a incorporação pode ser contratada mediante empreitada ou administração. Na primeira modalidade, o preço a ser pago pelo adquirente já é fixado no contrato, bem como seus eventuais índices de reajuste. Na administração, por outro lado, o preço é apenas estimado, sendo revisto de acordo com a progressão da obra pelo incorporador e pela comissão de representantes dos adquirentes.

${ }^{7} \mathrm{O}$ tema relativo às formas de captação de crédito imobiliário é bastante complexo e comporta diversas nuances, de modo que não se pode realizar sua análise aprofundada neste trabalho. É oportuna, de todo modo, a referência às Leis Federais 9.514/97, que regula o Sistema Financeiro Imobiliário, e 10.931/2004, que trata dos títulos de crédito imobiliários.
} 
certa equivalência; e de execução continuada, uma vez que o cumprimento do contrato se prolonga no tempo (CHALHUB, 2010, p. 150).

\section{APLICAÇÃO CONJUNTA DA LEI FEDERAL 4.591/64, DO CÓDIGO DE DEFESA DO CONSUMIDOR E DO CÓDIGO CIVIL NA TUTELA DO ADQUIRENTE}

A incorporação pode, por certo, constituir relação de consumo, atraindo a incidência da Lei Federal 8.078/90, que instituiu o CDC (ZULIANI, 2009, p. 241); na verdade, na maioria dos casos o fará, pois seus sujeitos tendem a enquadrar-se nas posições contratuais de fornecedor e consumidor, conforme definidas na mencionada lei (BRITO, 2002, p. 237).

$\mathrm{O}$ incorporador amolda-se ao conceito amplo de fornecedor do artigo $3^{\circ}$ do referido Código, já que é pessoa física ou jurídica que oferece ao mercado um serviço consistente na construção e entrega de um bem, de maneira não eventual. Age, pois, de maneira profissional, organizando fatores de produção para a consecução dos objetivos de seu empreendimento e, ao fim, o auferimento de lucro. O próprio artigo 31 da Lei Federal 4.591/64, citado anteriormente, restringe a função de incorporador a determinadas pessoas ${ }^{8}$ que, pela natureza de suas atividades, desempenham com pretensão de habitualidade o mister da incorporação.

A única das pessoas listadas no dispositivo em questão que poderia suscitar dúvidas quanto à profissionalidade e habitualidade de seu trabalho é o proprietário (ou promitente comprador e seu cessionário) do terreno. Todavia, a incorporação exige daquele que a empreende a mobilização de uma série de recursos e profissionais, de forma organizada, além do emprego de conhecimentos técnicos e da habilidade para conduzir as operações. $\mathrm{O}$ incorporador, assim, é sujeito abrangido pelo artigo $3^{\circ}$ do $\mathrm{CDC}$, porquanto não há meio de realizar sua atividade sem revestir-se das qualidades típicas de fornecedor. Aplica-se aqui raciocínio analógico àquele do artigo 966 do Código Civil, que caracteriza a figura do empresário 9 . Ao exercer de forma organizada e profissional sua atividade, gerando a circulação de bens e serviços, o incorporador explora empresa e, consequentemente, não pode fugir à qualificação de fornecedor (SCAVONE JÚNIOR, 2014, p. 185).

Tratando-se da alienação de unidades autônomas, a incorporação possui nítida embora não exclusiva - finalidade habitacional. Esta, em geral, destina-se ao sujeito que utiliza o bem de maneira final, retirando-o de circulação na forma do artigo $2^{\circ}$, caput do CDC,

\footnotetext{
${ }^{8}$ Nomeadamente, o proprietário (ou promitente comprador e seu cessionário) do terreno onde se realizará a incorporação, o construtor ou o corretor de imóveis.

9 Art. 966. Considera-se empresário quem exerce profissionalmente atividade econômica organizada para a produção ou a circulação de bens ou de serviços.

Revista da Faculdade de Direito - UFPR, Curitiba, vol. 60, n. 1, jan./abr. 2015, p. 163-192.
} 
para nele constituir sua residência. Dessa forma, o adquirente será, na maioria dos casos, consumidor - a não ser que utilize a unidade para o desenvolvimento de uma atividade econômica, não sendo, portanto, seu destinatário final (BRITO, 2002, p. 228).

A Lei Federal 4.591/64 possui um sistema próprio de proteção ao adquirente, limitando a autonomia das partes e estabelecendo para o incorporador deveres cujo descumprimento pode, inclusive, gerar consequências penais. É o caso, por exemplo, da negociação das unidades sem registro do memorial de incorporação e da recusa em outorgar a escritura ao adquirente (contravenções penais previstas respectivamente nos incisos I e III do artigo 66, da Lei Federal 4.591/64). Isso, contudo, não afasta a incidência da sistemática protetiva do CDC (GHEZZI, 2011, p. 155), pois o microssistema de proteção consumerista disciplina todas as relações entre os sujeitos identificados nos artigos $2^{\circ}$ e $3^{\circ}$ do referido Código, ainda que haja legislação própria para o tipo específico de vínculo entre as partes.

O CDC, enquanto lei geral posterior, não tem o condão de revogar os dispositivos da Lei Federal 4.591/64 que não sejam com ele conflitantes. Sua aplicação, assim, é primariamente integrativa, complementando eventuais lacunas deixadas pelo diploma especial no que se refere à tutela do adquirente consumidor. Contudo, se determinada prática não for vedada pela Lei Federal 4.591/64, mas se demonstrar incompatível com o sistema protetivo do CDC, restará configurada sua ilicitude.

O diálogo das fontes, portanto, deve ser feito com o intuito de proteger a parte mais fraca da relação jurídica - o consumidor (MARQUES, 2011, p. 276). Esse diálogo busca aproveitar o efeito útil das normas abstratamente incidentes sobre determinada relação, substituindo a lógica da mera revogação pela da coexistência entre as disciplinas legais (JAYME, 1995, p. 259). Dessa forma, nos pontos em que for mais protetivo e capaz de salvaguardar com maior adequação os direitos da parte vulnerável, o CDC deve prevalecer em relação a qualquer disposição legal especial. Quanto à Lei Federal 4.591/64 a questão é ainda mais simples, já que esta se trata de diploma anterior ao CDC; por conseguinte, tanto o critério cronológico quanto o da maior proteção do consumidor ${ }^{10}$ fundamentam a aplicação do Código com prevalência sobre a Lei da Incorporação. O STJ já se pronunciou em numerosas ocasiões nesse sentido, realizando o supracitado diálogo das fontes ${ }^{11}$.

\footnotetext{
${ }^{10} \mathrm{Na}$ Bauträgervertragsgesetz (BtVG) austríaca há expressa positivação de entendimento semelhante. Seu $\S 1.1$ aduz que dispositivos de outras leis que sejam mais favoráveis ao consumidor não serão afetados pela vigência da BtVG, de maneira que deve ser aplicada a norma que mais protege a parte vulnerável.

${ }^{11}$ Veja-se, por exemplo: Superior Tribunal de Justiça. Ag. Rg. no REsp. 1.006.765/ES. T3. Rel. Min. Ricardo Villas Bôas Cuevas. Julgado em 18/03/2014. DJe de 12/05/2014. 
Especificamente, para os fins deste artigo, a sistemática prevista pela Lei Federal 4.591/64 para a tutela do adquirente em casos de atraso na entrega do imóvel não exclui a aplicação do $\mathrm{CDC}$ - e, em virtude da referência feita pelo artigo $7^{\circ}$ deste último, permite-se a incidência suplementar da legislação ordinária, principalmente do Código Civil. Os dispositivos da Lei Federal 4.591/64 permanecem regulando a incorporação e parte das consequências da mora do incorporador; o CDC, atraído pela relação de consumo existente, embasará a proteção do consumidor adquirente em aspectos não contemplados pela Lei especial; e o Código Civil orientará de maneira suplementar a execução geral do contrato, especialmente no que tange ao seu descumprimento pelo atraso do fornecedor.

A Lei Federal 4.591/64 contém alguns mecanismos para punir e contornar o inadimplemento do incorporador. Seu artigo 43 estabelece que, havendo prazo de conclusão das obras determinado (ou determinável) no contrato, o incorporador deverá informar aos adquirentes semestralmente sobre o andamento da construção (inciso I) e, em caso de inexecução do termo avençado, será responsável civilmente (inciso II).

O inciso VI do mesmo artigo, por sua vez, trata da consequência mais severa gerada pela mora do fornecedor, ao determinar que, estando a obra paralisada injustificadamente por mais de trinta dias, o incorporador será notificado judicialmente para que continue os trabalhos. Não atendendo à notificação, os adquirentes podem votar por destituí-lo e, se quiserem, prosseguir em seu lugar na incorporação. Fazendo uso dessa faculdade legal, portanto, os compradores assumem a administração da obra e podem dar-lhe continuidade com seus próprios esforços (CHALHUB, 2010, p. 311). É certo que, não querendo, possuirão ainda o direito de resolução contratual (GHEZZI, 2011, p. 130).

A mora do incorporador pode apresentar também consequências penais. A paralisação da obra por mais de 30 dias ou seu retardamento excessivo, ausente justificativa, é conduta tipificada, no inciso VI do artigo 66 da Lei de Incorporação, como contravenção, punível com multa de cinco a vinte vezes o maior salário mínimo do País.

Esse é, em linhas gerais, o modelo instituído pela Lei Federal 4.591/64 para a tutela do consumidor adquirente em casos de atraso na entrega do imóvel. Conquanto contenha alguns delineamentos importantes, tais mecanismos jurídicos não bastam para o tratamento adequado da matéria. Faz-se necessário, assim, complementá-los a partir do diálogo com o CDC e com o Código Civil. A vulnerabilidade do consumidor, reconhecida pelo artigo $4^{\text {o, }}$ inciso I do CDC, reclama a aplicação de instrumentos legais aptos a proteger-lhe de forma efetiva, resguardando seus direitos básicos (NUNES, 2012, p. 177). Nesse contexto, verifica- 
se que o consumidor é destinatário de uma proteção jurídica especial por parte do Código (MIRAGEM, 2010, p. 35).

\section{A RESOLUÇÃO CONTRATUAL COMO DIREITO DO CONSUMIDOR EM CASO DE ATRASO NA ENTREGA DO IMÓVEL}

A resolução é forma de extinção do contrato, com efeitos ex tunc - o que retorna as partes ao estado anterior à contratação - causada pelo inadimplemento de um dos contratantes (AGUIAR JÚNIOR, 2012, p. 501). O contrato pode conter cláusula resolutiva expressa; contudo, mesmo ausente sua previsão no instrumento negocial, a parte prejudicada pela inexecução pode requerer judicialmente a resolução, conforme o artigo 475 do Código Civil ${ }^{12}$. É certo que o descumprimento apto a resolver o contrato não é aquele de pequena monta. A teoria do adimplemento substancial ${ }^{13}$, corolário do princípio da boa-fé objetiva (artigo 422 do Código Civil), determina que a resolução apenas terá lugar quando a prestação tenha sido inadimplida de maneira relevante, não mais interessando a seu credor (FARIAS; ROSENVALD, 2012a, p. 555).

Considerando o disposto no artigo 43, inciso VI, da Lei Federal 4.591/64, que permite a destituição do incorporador mediante a maioria dos votos dos adquirentes, sendolhes facultado prosseguir na obra ou resolver o contrato, poder-se-ia pensar que nos contratos de incorporação a resolução só teria lugar quando, mediante votação dos adquirentes, fosse destituído o incorporador e não se desse continuidade à obra. Isso, como se vê, limitaria significativamente o direito do consumidor à resolução, já que esta dependeria da aprovação da maioria dos demais compradores. É nesse ponto que se faz necessário aplicar o CDC, de forma a adequadamente tutelar os interesses do consumidor adquirente.

Quando o incorporador (fornecedor) divulga seu empreendimento e oferece as unidades autônomas do edifício ao mercado, estabelecendo um prazo para conclusão das obras, opera-se a vinculação da oferta a que se refere o artigo 30 do CDC. O fornecedor, portanto, não poderá impunemente fugir ao cumprimento das condições estabelecidas na oferta, pois se presume absolutamente que estas influenciaram o consumidor em sua escolha

\footnotetext{
${ }^{12}$ Art. 475. A parte lesada pelo inadimplemento pode pedir a resolução do contrato, se não preferir exigir-lhe o cumprimento, cabendo, em qualquer dos casos, indenização por perdas e danos.

${ }^{13} \mathrm{O}$ conceito de adimplemento substancial foi desenvolvido jurisprudencialmente no direito norte-americano ainda no começo do século XX, sob o nome de doctrine of substantial performance. Ainda que seus contornos fossem levemente diferentes dos que hodiernamente lhe são conferidos, a teoria em questão propunha que pequenas violações do contrato não poderiam limitar os direitos da parte violadora à obtenção da prestação de sua contraparte (COBIN, 1919, p. 759). Esta não poderia requerer a resolução do contrato; caber-lhe-ia, somente, a reparação civil por perdas e danos.

Revista da Faculdade de Direito - UFPR, Curitiba, vol. 60, n. 1, jan./abr. 2015, p. 163-192.
} 
pelo bem ou serviço adquirido (MARQUES, 2011, p. 760). O artigo 35 do CDC prevê as possibilidades colocadas à disposição do consumidor quando houver descumprimento da oferta, quais sejam: a execução específica da obrigação (inciso I) ${ }^{14}$, a aceitação de produto ou serviço equivalente (inciso II) ${ }^{15}$ e a resolução do contrato (inciso III).

Quando o negócio é finalmente celebrado, com mais razão, o fornecedor é obrigado a cumprir o que está nele previsto - inclusive o prazo de finalização da incorporação; trata-se de simples aplicação do vetusto princípio da força obrigatória do contrato (GAGLIANO; PAMPLONA FILHO, 2012, p. 76). Incidem, assim, os artigos do Código Civil que disciplinam o tema - inclusive o artigo 475, que positiva o direito de resolução contratual.

O fato de a Lei Federal 4.591/64 somente prever a possibilidade de resolução na forma do artigo 43, inciso VI, não pode excluir a aplicação dos dispositivos do CDC e do Código Civil. Deve se empreender o diálogo das fontes para definir a interpretação dos dispositivos que ofereça melhor tutela ao consumidor (MARQUES, 2011, p. 726).

A tradicional teoria do negócio jurídico compreende o direito de resolução como uma ferramenta de justiça contratual, colocada à disposição da parte lesada para equilibrar a relação cujo balanço foi afetado pelo inadimplemento (BETTI, 1970, p. 73). Restringir a viabilidade de seu uso à votação a que se refere o artigo 43, inciso VI, da Lei Federal 4.591/64, seria retirar, do consumidor, importante instrumento de defesa de seus interesses.

Se na relação contratual civil já se reconhece a importância da resolução como meio de equilíbrio entre as partes, com mais razão deve se admitir seu amplo manejo pelo consumidor, parte vulnerável da relação de consumo, independentemente do procedimento previsto no artigo 43, inciso VI da Lei Federal 4.591/64. Sendo assim, qualquer consumidor que se sentir lesado pelo atraso na entrega do imóvel e em virtude disso perder o interesse na aquisição do mesmo poderá requerer a resolução do contrato, mesmo que a maioria dos adquirentes prefira não destituir o incorporador. Raciocínio diverso implicaria indevida limitação de seus direitos, forçando o consumidor a continuar vinculado a um contrato que não lhe é mais objetivamente útil ou financeiramente interessante ${ }^{16}$.

\footnotetext{
${ }^{14}$ A execução específica quanto à data de entrega prevista é inaplicável aos casos de atraso na entrega do imóvel. Afinal, uma vez transcorrido o prazo de conclusão das obras, seu descumprimento se consuma de forma irreversível. O consumidor poderá, entretanto, exigir que o incorporador entregue o edifício tão cedo quanto for possível.

${ }_{15}$ Essa hipótese se insere na autonomia privada das partes, já que o texto legal fala em "aceitação" do consumidor - o que pressupõe uma proposta do fornecedor - configurando novo negócio jurídico. Sua aplicação, portanto, não cria maiores dificuldades dogmáticas, razão pela qual o presente estudo não se deterá sobre ela.

${ }^{16}$ A jurisprudência superior tem acolhido exatamente esse entendimento. Confira-se, por exemplo: Superior Tribunal de Justiça. REsp. 1.049.894/RJ. T3. Rel. Vasco Della Giustina. Julgado em 21/09/2010. DJe de $29 / 09 / 2010$.
} 


\subsection{ASPECTOS PROCESSUAIS DA RESOLUÇÃO}

Há ainda algumas repercussões processuais da argumentação aqui traçada. Enquanto tramitar a ação judicial em que se pede a resolução, o consumidor poderá efetuar o depósito judicial das parcelas do pagamento do imóvel, com o intuito de salvaguardar-se contra os efeitos da mora em caso de improcedência de seu pedido ao final do processo.

O manejo do artigo 273 do Código de Processo Civil de 1973 (correspondente ao artigo 298 do novo $\mathrm{CPC})^{17}$ também será possível. Mediante requerimento do adquirente, o juiz poderá, presentes os requisitos legais, antecipar a tutela para considerar resolvido o contrato, desobrigando o consumidor de realizar o pagamento das prestações ao longo do processo (RAMOS; ARAÚJO JÚNIOR, 2012, p. 68). Outrossim, é plausível que o adquirente pleiteie a tutela de urgência para, ao invés de promover a resolução, apenas autorizar a suspensão do pagamento das prestações enquanto durar o litígio, com fundamento na exceptio non adimpleti contractus (exceção do contrato não cumprido) do artigo 476 do Código Civil $^{18}$.

Esse entendimento, contudo, está longe da unanimidade. Ainda se encontram decisões que negam o direito do consumidor à suspensão dos pagamentos ${ }^{19}$, exigindo que se realize ampla instrução do processo para tanto - o que nulifica a própria finalidade da tutela antecipada nesses casos, a qual se funda em juízo de cognição sumária. A "probabilidade do direito" a que se refere o artigo 298 do Código de Processo Civil atual deve considerar a dificuldade probatória do consumidor, bem como a urgência de sua realização (MARINONI; ARENHART, 2012, p. 209), de maneira a não inviabilizar a proteção dos direitos da parte vulnerável. Ademais, a inversão do ônus da prova, contida no artigo $6^{\circ}$, inciso VIII, do CDC, pode ser utilizada nessas situações para embasar a concessão da tutela antecipada, transmitindo ao fornecedor o encargo de demonstrar a falsidade das alegações do requerente.

Não é necessário, assim, que se realize extensa instrução probatória antes de se autorizarem as medidas referidas. Basta que o consumidor demonstre o vínculo entre ele e o incorporador, o prazo para conclusão das obras e o seu descumprimento. Os dois primeiros itens podem ser provados pela simples exibição do instrumento contratual, sendo que o prazo

\footnotetext{
17 Art. 298. A tutela de urgência será concedida quando houver elementos que evidenciem a probabilidade do direito e o perigo de dano ou o risco ao resultado útil do processo.

${ }^{18}$ Essa possibilidade (de suspensão do pagamento das parcelas com espeque no art. 476 do Código Civil, em sede de tutela antecipada) já foi reconhecida na jurisprudência pátria. Veja-se, nesse sentido: Tribunal De Justiça do Estado da Bahia. Ag. Inst. 0310760-03.2012.8.05.0000. $3^{\mathrm{a}}$ Câmara Cível. Rel. Des. Heloísa Pinto de Freitas Vieira Graddi. Julgado em 05/11/2013.

${ }^{19}$ Veja-se, por exemplo: Tribunal de Justiça do Distrito Federal. Ag. Reg. no Ag. Inst. 20130020279543. $1^{\mathrm{a}}$ Turma Cível. Rel. Des. Simone Lucindo. Julgado em 11/12/2013. DJe de 07/01/2014.

Revista da Faculdade de Direito - UFPR, Curitiba, vol. 60, n. 1, jan./abr. 2015, p. 163-192.
} 
também pode ser demonstrado, por exemplo, por meio de anúncios publicitários que o contenham. Quanto à prova do atraso, qualquer meio idôneo será apto a produzi-la - como fotos das obras ou certidão atestando a falta do habite-se. O que não é coerente é que se exija a conclusão da fase instrutória do processo para que se defira a tutela antecipada, já que o juízo a ser realizado pelo magistrado, quando da concessão da medida, é de verossimilhança e não necessariamente de certeza (DIDIER JÚNIOR; BRAGA; OLIVEIRA, 2012, p. 501).

\subsection{A ABUSIVIDADE DA CLÁUSULA CONTRATUAL QUE DETERMINA A RESTITUIÇÃO PARCIAL DOS VALORES}

A resolução contratual gera efeitos ex tunc (ou seja, que retroagem à data da contratação), de modo que as partes devem restituir uma à outra aquilo que anteriormente haviam pagado (AGUIAR JÚNIOR, 2012, p. 508). Afinal, a intenção do instituto é retornálas tanto quanto possível à mesma situação em que estavam antes da celebração do contrato, como se o mesmo nunca tivesse sido realizado.

Não obstante, é comum, nos contratos de incorporação, cláusula que determina a restituição parcial dos valores pagos pelo adquirente, em caso de resolução. Essa determinação justifica-se quando a extinção do negócio é imputável ao consumidor, seja em virtude da ausência de condição financeira de prosseguir com os pagamentos ou mesmo pelo desinteresse superveniente na aquisição. Nestes casos, o consumidor recebe de volta parte dos valores já pagos, enquanto o restante fica com o incorporador como compensação pela perda da venda. O que não se pode é instituir no contrato a hipótese da perda total das parcelas já pagas pelo adquirente (CHALHUB, 2010, p. 417).

Em casos de resolução a que o incorporador deu causa, todavia - como ocorre no atraso na entrega do imóvel - não há razão para que assim se proceda. O consumidor, nessas situações, não teve qualquer responsabilidade pela extinção contratual, que foi motivada unicamente pela mora do fornecedor. Não se pode, portanto, impor-lhe obrigação em favor do incorporador quando fundada em atraso na entrega a que este último deu causa ${ }^{20}$.

A retenção de certa fração das quantias pagas pelo adquirente tem, em verdade, natureza jurídica de reparação por perdas e danos (CHALHUB, 2010, p. 414), destinadas a ressarcir o fornecedor pelos custos transacionais e pela perda da oportunidade de efetuar a venda do imóvel. Contudo, quando é o próprio incorporador que dá causa à resolução, é ele que causa prejuízo ao consumidor - e não o contrário.

\footnotetext{
${ }^{20}$ O § 309.6 do Bürgerliches Gesetzbuch (BGB), o Código Civil alemão, aliás, expressamente veda a fixação de penalidade para o contratante que solicita a resolução do contrato em virtude de inadimplemento da outra parte.

Revista da Faculdade de Direito - UFPR, Curitiba, vol. 60, n. 1, jan./abr. 2015, p. 163-192.
} 
Permitir a restituição parcial das quantias pagas, em tais casos, equivale a proteger o fornecedor contra sua própria desídia. A cláusula que o faça deve ser considerada abusiva e, como tal, nula de pleno direito (artigo 51 do CDC) e passível de ser assim reconhecida ex officio pelo magistrado (NUNES, 2012, p. 722). A declaração de sua nulidade (ex tunc), ademais, faz com que a cláusula não gere efeitos, impedindo-a de vincular de qualquer maneira o consumidor (AZEVEDO, 2010, p. 64). Embora não se possa enquadrá-la em nenhum item específico dentre os contidos no artigo 51 do $\mathrm{CDC}^{21}$, é possível valer-se da provisão geral do inciso $\mathrm{IV}^{22}$ do mesmo artigo, que veda o estabelecimento de obrigações incompatíveis com a sistemática protetiva consumerista (MARQUES, 2011, p. 972). À luz do $\S 1^{\circ}$, inciso III, do artigo 51 , pode considerar-se que a cláusula em questão cria vantagem excessiva para o fornecedor, em prejuízo do consumidor, já que assegura o primeiro contra sua própria negligência.

Todos os valores pagos pelo consumidor, a qualquer título, deverão ser restituídos, com juros legais na forma do artigo 406 do Código Civil, devidos a partir da citação do incorporador $^{23}$, e correção monetária, com termo inicial na data do pagamento. Afinal, já que se destina a recompor a perda do valor da moeda, a correção deve incidir a partir do momento em que o consumidor foi privado da propriedade do dinheiro pago, de maneira a reintegrá-lo ao status quo. A jurisprudência pátria vem caminhando nesse sentido, embora ainda haja certa divergência quanto a determinados valores - como as taxas de corretagem e de assessoria imobiliária, por exemplo ${ }^{24}$. De toda forma, a tendência predominante, seguida inclusive pelo Superior Tribunal de Justiça (STJ), é a de determinar a restituição integral da quantia paga ${ }^{25}$.

\footnotetext{
${ }^{21}$ A hipótese guarda certa semelhança com o caso do inciso II do artigo 51; de todo modo, ainda que não se possa amoldá-la a esse inciso, o reconhecimento da abusividade da cláusula ainda se imporá, em virtude da norma geral do inciso IV.

${ }^{22}$ A redação do dispositivo é bem semelhante à do $\S 307.1$ do $\mathrm{BGB}$, que proíbe cláusulas contrárias à boa-fé, discriminatórias ou que criem obrigação excessivamente onerosa para a outra parte, especialmente tratando-se de contratos de adesão. O $\S 307.2$, que define as hipóteses de onerosidade excessiva da obrigação, tem conteúdo quase igual ao dos incisos do $\S 1^{\circ}$ do artigo 51 do CDC.

${ }^{23}$ Importa ressaltar que, neste ponto, existe certa controvérsia. O enunciado $\mathrm{n}^{\mathrm{o}} 428$ do Conselho da Justiça Federal aduz que o termo inicial de contagem dos juros de mora só coincide com a citação quando esta tem o papel de notificação do devedor, ou em caso de obrigações ilíquidas. Como nos contratos de aquisição de imóvel é rara a cláusula que prevê a restituição total dos valores pagos pelo consumidor em caso de atraso na entrega, a obrigação de fazê-lo é, geralmente, fixada na via judicial, de maneira que o marco temporal do artigo 405 do Código Civil (qual seja, a citação) pode ser o mais adequado para a fluência dos juros.

${ }^{24}$ Confira-se, excluindo a taxa de corretagem da obrigação de restituição: Tribunal de Justiça do Estado do Rio Grande do Sul. RC 71004720959. $1^{\text {a }}$ Turma Recursal Cível. Rel. Marta Borges de Ortiz. Julgado em 15/07/2014. DJ de 16/07/2014.

${ }^{25}$ Superior Tribunal de Justiça. Ag. Reg. no Ag. Inst. 1.161.069/RJ. T4. Rel. Min. Luís Felipe Salomão. Julgado em 16/02/2012.
}

Revista da Faculdade de Direito - UFPR, Curitiba, vol. 60, n. 1, jan./abr. 2015, p. 163-192. 


\section{POSSIBILIDADES DE RESPONSABILIZAÇÃO CIVIL DO INCORPORADOR EM ATRASO}

Tendo o adquirente optado ou não pela resolução do contrato, é certo que o atraso na entrega do imóvel configura uma espécie de inadimplemento do incorporador - o que, no tradicional âmbito da teoria geral das obrigações, gera o dever de indenizar a contraparte pelas perdas e danos (FARIAS; ROSENVALD, 2012b, p. 591). A inexecução causa também transtornos não patrimoniais ao consumidor adquirente, já que essa situação tende a repercutir de forma significativa sobre seu próprio plano de vida. Afinal, a compra de um imóvel - com fins habitacionais ou mesmo de locação - é projeto que, em geral, ocupa grande importância existencial para o consumidor. É importante ressaltar, nesse contexto, que a reparação dos danos (patrimoniais e extrapatrimoniais) sofridos é estabelecida como direito básico do consumidor pelo artigo $6^{\circ}$, inciso VI, do CDC (BENJAMIN; MARQUES; BESSA, 2012, p. $75)$.

Impende, portanto, separar em duas ordens a responsabilidade indenizatória do incorporador: a patrimonial, consistente nas perdas e danos, e a extrapatrimonial. Saliente-se que, em qualquer dos casos, o incorporador responderá objetivamente, independentemente de culpa (ALMEIDA, 2011, p. 85), conforme o artigo 43, inciso II, da Lei Federal 4.591/64, combinado com os artigos 12 e 14 do CDC (CHALHUB, 2010, p. 330). Devem ser consideradas, no que forem aplicáveis, as excludentes de responsabilidade do artigo $12, \S 3^{\circ}$, do $\mathrm{CDC}^{26}$. Ao adotar a teoria do risco do negócio - e não do risco integral - o CDC admite o afastamento da responsabilidade do fornecedor em determinados casos, todos relacionados à inexistência de sua participação no resultado danoso (SANSEVERINO, 2010, p. 279).

\subsection{INDENIZAÇÃO POR PERDAS E DANOS}

A inexecução de uma obrigação contratual gera, para a parte lesada, prejuízo patrimonial - as perdas e danos - que deverá ser reparado pela inadimplente, com o objetivo de restaurar o contratante prejudicado ao estado econômico em que se encontraria caso a obrigação tivesse sido cumprida (FARBER, 1980, p. 1443). A reparação é devida não só em casos de resolução do contrato, mas também nas situações em que a parte afetada decida prosseguir na execução do mesmo (artigo 475 do Código Civil).

\footnotetext{
${ }^{26}$ Art. $12, \S 3^{\circ}$. O fabricante, o construtor, o produtor ou importador só não será responsabilizado quando provar: I - que não colocou o produto no mercado; II - que embora haja colocado o produto no mercado, o defeito inexiste; III - a culpa exclusiva do consumidor ou de terceiro.

Revista da Faculdade de Direito - UFPR, Curitiba, vol. 60, n. 1, jan./abr. 2015, p. 163-192.
} 
A extensão das perdas e danos vem definida no artigo 402 do Código Civil, abrangendo os danos emergentes e os lucros cessantes. O damnum emergens é o prejuízo consistente na diferença entre a situação patrimonial do credor antes do contrato e a posterior ao inadimplemento (PEREIRA, 2011, p. 317); trata-se, na expressão utilizada pelo artigo 402 do Código Civil, do que o credor "efetivamente perdeu".

Os lucros cessantes, por outro lado, são expressos na vantagem que a parte lesada auferiria caso a obrigação tivesse sido cumprida na forma estipulada. Sua definição é, portanto, estimada, tendo como referencial o benefício econômico que razoavelmente se poderia esperar da fruição do objeto da obrigação. Apenas a perda oriunda diretamente da inexecução é que deve ser computada no cálculo, ignorando-se o dano remoto, em virtude da própria redação do artigo 403 do Código Civil (SILVA, 2010, p. 330).

A fórmula adotada pela legislação civil foi, assim, a soma do substitutive price (ou "preço substitutivo", correspodente aos danos emergentes) e do lost surplus (ou "lucro perdido", equivalente aos lucros cessantes), que figura entre as mais comuns para a delimitação da indenização por perdas e danos ${ }^{27}$. Esta deverá ser paga, ademais, com juros legais (artigos 404 e 405 do Código Civil) e correção monetária (artigo 404 do Código Civil).

O atraso na entrega do imóvel pode, sem dúvida, causar prejuízos das duas espécies legais ao adquirente. A fixação de penalidade contratual, aliás, não limita a indenização a ser paga pelo incorporador, já que constitui mera previsão de perdas e danos que admite complementação posterior. Afinal, conforme o artigo 410 do Código Civil, a cláusula penal compensatória (referente ao inadimplemento total da obrigação) é alternativa colocada à disposição do credor, que pode preferir a liquidação das perdas e danos e execução da quantia correspondente (FARIAS; ROSENVALD, 2012b, p. 635) ${ }^{28}$. Além disso, o artigo 25 do CDC pró́be a limitação contratual da responsabilidade do fornecedor ${ }^{29}$, de maneira que o consumidor poderá pleitear a reparação ainda que em montante superior ao da cláusula penal.

\footnotetext{
${ }^{27}$ Há, ainda, outras formas para o cálculo das perdas e danos. É o caso, por exemplo, da opportunity cost, que cobre a perda da chance de ter celebrado outro contrato no lugar do que foi descumprido, e da out of pocket cost, que incide sobre os custos de transação com a celebração do contrato (COOKER, 1985, p. 1439).

${ }_{28}$ A questão, nesse ponto, implica mitigação do disposto no parágrafo único do artigo 416 do Código Civil, que condiciona a possibilidade de indenização suplementar à prévia permissão para tanto no instrumento contratual. Mesmo nas relações civis, o STJ, no julgamento do REsp. 734.520/MG (4 ${ }^{\mathrm{a}}$ Turma, Rel. Min. Hélio Quaglia Barbosa, julgado em 21/06/2007 e publicado em 15/10/2007), começou a se pronunciar pela desnecessidade da referida pactuação. Nas relações de consumo, com mais razão (em virtude do artigo 25 do CDC, que veda a limitação contratual da responsabilidade do fornecedor), deve ser entendido que o valor pactuado na cláusula penal é alternativa à disposição do consumidor, que pode preferir a liquidação das perdas e danos.

${ }_{29}$ Recorrendo novamente ao direito alemão, o parágrafo 309.7 , b, do BGB, proíbe a cláusula limitadora da responsabilidade do contratante que descumpre suas obrigações com "excessiva negligência". Embora se trate de uma sistemática de responsabilidade subjetiva - diversa, pois, do modelo objetivo adotado pelo CDC - o Revista da Faculdade de Direito - UFPR, Curitiba, vol. 60, n. 1, jan./abr. 2015, p. 163-192.
} 
No que tange aos danos emergentes, o incorporador deverá indenizar o consumidor por todos os gastos que este teve com a privação da possibilidade de utilizar o imóvel. Se, por exemplo, o consumidor residia em local alugado e almejava mudar-se para o edifício cuja fração ideal adquiriu, a despesa com o aluguel (durante o atraso) deverá integrar o cálculo dos danos emergentes. A prova da quantia poderá ser feita pela exibição do contrato de locação ou pelos recibos do pagamento ao locador - ou até mesmo pelo testemunho deste, na inexistência de contrato escrito ${ }^{30}$. Quando os gastos puderem ser provados de forma simples (v.g., pela via documental), e fazendo-se presentes os requisitos do artigo 273, inciso I, do Código Civil ${ }^{31}$, será possível a concessão de tutela antecipada já no início do processo, mediante cognição sumária e sem necessidade de um procedimento de liquidação específico ${ }^{32}$.

Quanto aos lucros cessantes, a hipótese clássica é a do adquirente que pretende utilizar o imóvel comprado não para nele residir, mas sim para destiná-lo à locação. Essa destinação econômica do bem não necessariamente desqualifica o adquirente como consumidor. Afinal, a atividade de locação residencial disciplinada na Lei Federal 8.245/91 não se reveste obrigatoriamente de caráter empresarial e o locador não é, em geral, tido como fornecedor para efeitos de incidência do CDC. Não seria razoável, portanto, negar-lhe o status de consumidor frente ao incorporador ${ }^{33}$. Ressalte-se que o valor a ser pago por este, como reparação por lucros cessantes, deve ser acrescido de juros legais e de correção monetária.

A quantia dos lucros cessantes pode ser definida por meio da análise do aluguel que razoavelmente se cobraria do imóvel caso estivesse pronto, considerando-se os preços aplicáveis a imóveis em condições, tamanho e localização semelhantes. A prova pericial -

dispositivo chama atenção por vedar, mesmo em contratos civis, a limitação da responsabilidade do contratante que age com desídia; mais razão há, portanto, para aplicar entendimento análogo nas relações de consumo.

${ }^{30} \mathrm{Da}$ mesma forma, se o valor do IPTU da residência alugada for maior que o do imóvel comprado (e a responsabilidade pelo imposto for do consumidor), os danos emergentes deverão considerá-lo. Igual raciocínio pode ser aplicado às taxas condominiais e outros gravames que incidam sobre o imóvel alugado e que seriam menos custosos no bem objeto da incorporação. É necessário, portanto, incluir na fixação dos danos emergentes toda despesa adicional com que o consumidor é obrigado a arcar em virtude da mora do incorporador (RAMOS; ARAÚJO JÚNIOR, 2012, p. 68).

${ }^{31}$ Quais sejam, a verossimilhança das alegações do autor e o perigo de dano irreparável ou de difícil reparação.

${ }^{32}$ Confira-se, nesse sentido: Tribunal de Justiça do Estado de Minas Gerais. Ag. Inst. 10024131788796002. 18 Câmara Cível. Rel. Des. João Cancio. Julgado em 25/03/2014.

${ }^{33}$ Ao destinar o bem à locação o adquirente não será desqualificado como consumidor, independentemente do entendimento que se adote quanto à delimitação do conceito do artigo $2^{\circ}$ do CDC. Afinal, mesmo para a teoria finalista - a mais restritiva das correntes doutrinárias e jurisprudenciais - o adquirente seria tido como destinatário final do imóvel, já que não o empregaria profissionalmente em outra atividade de caráter produtivo (MARQUES, 2011, p. 304). A locação, nesse caso, constituiria mero exercício do poder de fruição do bem, sem a presença de qualquer elemento de empresa apto a caracterizar o adquirente como fornecedor.

Revista da Faculdade de Direito - UFPR, Curitiba, vol. 60, n. 1, jan./abr. 2015, p. 163-192. 
com a participação de um corretor legalmente habilitado, por exemplo - certamente será importante nessa tarefa, que exige conhecimentos específicos do mercado imobiliário ${ }^{34}$.

Em virtude dessa peculiaridade probatória, existe certa resistência jurisprudencial em admitir o uso da tutela antecipada, no começo do processo, para obrigar o incorporador ao pagamento de lucros cessantes - impondo ao consumidor o ônus de aguardar a perícia ${ }^{35}$. Esse entendimento, todavia, não se afigura como o mais adequado. Como a tutela antecipada, na fase processual postulatória, satisfaz-se com um juízo de cognição sumária (MARINONI; ARENHART, 2012, p. 209), a prova que demonstre o valor aproximado de locação do imóvel (v.g., o extrato de uma pesquisa na internet ou cópia dos classificados do jornal) pode embasar seu deferimento. Lembre-se, ainda, que o magistrado pode fazer uso do artigo $6^{\circ}$, inciso VIII, do CDC, e, convencendo-se da verossimilhança do preço apontado pelo consumidor, inverter o ônus da prova e conceder-lhe a antecipação dos efeitos da tutela.

É certo que não caberá a cumulação própria dos pedidos de indenização por danos emergentes, em virtude dos gastos do adquirente com aluguel de sua residência, e de lucros cessantes, pela impossibilidade de perceber alugueres do imóvel cuja entrega foi adiada. As hipóteses são mutuamente excludentes, já que o consumidor não pode, ao mesmo tempo, morar no imóvel objeto da incorporação e alugá-lo a um terceiro. Deverá, pois, formular apenas um dos pedidos - ou cumulá-los alternativamente, caso não tenha decidido qual finalidade concederá ao bem.

\subsection{INDENIZAÇÃO POR DANO EXTRAPATRIMONIAL}

Além de causar prejuízos de ordem material ao consumidor, o atraso na entrega do imóvel também lhe impõe transtornos de diversas outras ordens. A definição de um local para habitação - finalidade mais comum da incorporação imobiliária - é, por certo, um dos interesses mais importantes na vida do cidadão, influindo sobremaneira no livre desenvolvimento de sua personalidade. $\mathrm{Na}$ verdade, ainda que o consumidor não deseje habitar na unidade adquirida, a destinação econômica que desejava dar-lhe é prejudicada pelo atraso, o que pode repercutir em sua esfera emocional. $\mathrm{O}$ investimento necessário para a aquisição de um imóvel por meio de negócio de incorporação não costuma ser módico, exigindo significante planejamento financeiro e direcionamento de esforços pessoais por parte

\footnotetext{
${ }^{34}$ Tribunal de Justiça do Distrito Federal. Ap. Cív. 20130710013083. $3^{\text {a }}$ Turma Recursal dos Juizados Especiais Cíveis. Rel. Edi Maria Coutinho Bizzi. Julgado em 11/02/2014. DJe de 27/02/2014.

${ }^{35}$ Tribunal de Justiça do Estado do Rio Grande do Sul. Ag. Inst. 70058480120. 19ª Câmara Cível. Rel. Des. Mylene Maria Michel. Julgado em 29/04/2014. 
do consumidor. A demora na entrega do bem, pois, não gera reflexos meramente patrimoniais, mas tende a projetar efeitos que ultrapassam a referida seara, incidindo, v.g., sobre as emoções, a paz e a tranquilidade do adquirente.

Essa projeção enquadra-se, por exemplo, no conceito tradicional de dano moral, compreendido como o prejuízo resultante da violação de um bem jurídico atinente à personalidade e sentimentos do sujeito (CAVALIERI FILHO; DIREITO, 2004, p. 100), tanto em relação às suas emoções pessoais como no que se refere à sua imagem social (MICHELLAZZO, 2000, p. 15). A própria Constituição Federal, em seu artigo $5^{\circ}$, incisos V e $\mathrm{X}$, garante o direito à indenização pelo dano moral, enquanto o $\mathrm{CDC}$, no artigo $6^{\circ}$, inciso VI, lista-o como direito básico do consumidor. Ademais, a Súmula $n^{\circ} 37$ do STJ permite a cumulação das indenizações pelos danos material e moral, quando provenientes do mesmo fato (CAHALI, 2011, p. 44).

O dano moral pode originar-se de descumprimento contratual, ainda que o mero inadimplemento geralmente não seja, por si só, suficiente para caracterizá-lo. O magistrado deve ponderar as características específicas do contrato, sua relevância existencial e as expectativas que criou na parte lesada, bem como os esforços por ela investidos em sua execução, para decidir pela existência ou não do dano. Havendo, portanto, razões para crer que o inadimplemento teve repercussão extrapatrimonial negativa relevante, deve se reconhecer a ocorrência do dano. Tratando-se de relação contratual de consumo (LISBOA, 2006, p. 254), existe razão ainda mais forte para esse entendimento, uma vez que a responsabilidade do fornecedor é objetiva (artigos 12 e 14 do CDC) e, portanto, dispensa a comprovação de culpa na provocação do prejuízo.

As apontadas peculiaridades da incorporação imobiliária, especialmente no que se refere à importância desta para o consumidor e ao aporte de recursos por este realizado, demonstra que o descumprimento da avença pelo incorporador é plenamente capaz de provocar o dano que ora se estuda (CAHALI, 2011, p. 511). A questão que poderia se colocar como obstáculo é a da produção de prova capaz de demonstrar a ocorrência do prejuízo ao adquirente. Em que pese a distribuição de ônus probatório ao autor quanto aos fatos constitutivos de seu direito - e, nesse caso, quanto à configuração do dano (MICHELLAZZO, 2000, p. 34) - prevista no artigo 371, inciso I, do Código de Processo Civil, o dano em tais casos prescindirá de prova.

Determinadas espécies de dano moral, caracterizadas como dano moral puro ou in re ipsa, são de ocorrência presumida após o acontecimento de certos fatos, não necessitando de comprovação específica (THEODORO JÚNIOR, 2010, p. 148). O que deverá ser provado é o 
evento que lhes deu origem. É que, em certas situações, a prática de um ato ilícito tem repercussões morais tão severas que provavelmente afetaria qualquer pessoa na mesma situação, o que dispensa a comprovação específica do dano (MICHELLAZZO, 2000, p. 43). É o caso, por exemplo, da inscrição indevida de consumidor em cadastro de inadimplentes (THEODORO JÚNIOR, 2010, p. 181).

Considerando-se as características supracitadas do dano causado pelo atraso na incorporação imobiliária deve-se, por conseguinte, reconhecer a sua caracterização in re ipsa, incumbindo ao consumidor provar apenas a prática do ilícito contratual por parte do incorporador. O prejuízo moral deverá ser presumido, cabendo ao magistrado valorar a gravidade das circunstâncias do caso para definição do quantum indenizatório. O próprio STJ já reconheceu a validade desta argumentação, ao compreender o atraso como causador de dano moral in re ipsa ${ }^{36}$. A jurisprudência nacional, todavia, ainda parece resistente a esse entendimento, tendendo a visualizar a mora do fornecedor como simples inadimplemento contratual, que não causa mais do que um aborrecimento comum ${ }^{37}$. Esta orientação pretoriana merece ser modificada, tendo em vista os fundamentos anteriormente delineados.

\section{ANÁLISE DA CLÁUSULA QUE ESTABELECE PRAZO DE TOLERÂNCIA PARA O INCORPORADOR}

A atividade do incorporador, por envolver também a construção do edifício cujas frações ideais serão alienadas, submete-se a diversos fatores nem sempre controláveis e que podem alterar significativamente o andamento das obras. Paralisações prolongadas de trabalhadores do setor e intempéries climáticas inesperadas são apenas alguns exemplos dessa constatação (PEREIRA, 2014, p. 260 e s.). É por isso que a quase totalidade dos contratos de compra e venda no negócio de incorporação possui cláusula que estabelece um prazo de tolerância para a conclusão das obras, permitindo ao incorporador recuperar-se de transtornos ocorridos durante a construção (RAMOS; ARAÚJO, 2012, p. 67).

Essa previsão, abstratamente, não se apresenta em discordância com a sistemática protetiva estabelecida pelo CDC ou pela Lei Federal 4.591/64. As dificuldades da incorporação justificam, em determinadas situações, concessões ao fornecedor (CHALHUB, 2010, p. 357); se o consumidor for satisfatoriamente informado - inclusive com o destaque a

\footnotetext{
${ }^{36}$ Superior Tribunal de Justiça. Ag. Reg. no Ag. Inst. 1.161.069/RJ. T4. Rel. Min. Luís Felipe Salomão. Julgado em 16/02/2012.

${ }^{37}$ Tribunal de Justiça do Estado do Rio Grande do Sul. RC 71004282810. $1^{\text {a }}$ Turma Recursal Cível. Rel. Roberto José Ludwig. Julgado em 30/04/2013. DJ de 03/05/2013.

Revista da Faculdade de Direito - UFPR, Curitiba, vol. 60, n. 1, jan./abr. 2015, p. 163-192.
} 
que se refere o artigo $54, \S 4^{\circ}$ do $\mathrm{CDC}$ - e concordar expressamente, não se vê problemas em sua utilização. O que não se pode permitir, todavia, é que o prazo de tolerância se converta em verdadeira carta branca para o incorporador, validando qualquer tipo de atraso de sua parte.

$\mathrm{Na}$ doutrina inglesa, as cláusulas contratuais que estabelecem isenções para o construtor - o que inclui a prerrogativa de descumprir o prazo para conclusão das obras - as chamadas exemption clauses, são tratadas com bastante rigor. Quando a relação jurídica é de consumo, há uma dupla exigência para a validade objetiva da previsão. Primeiramente, a cláusula deve atender ao mandamento de razoabilidade, restringindo-se ao mínimo necessário para viabilizar o objetivo a que se destina; em segundo lugar, o consumidor deve manifestar aquiescência expressa à provisão (MURDOCH; HUGUES, 2008, p. 152). Além disso, por meio da aplicação da regra contra proferentem, a dúvida na interpretação da cláusula decidese contra aquele que a formulou - o fornecedor (BOARDMAN, 2006, p. 1121). Vigora, pois, a noção de que cabe ao elaborador do contrato, geralmente de adesão, o dever de fazê-lo com linguagem clara, e de informar ao consumidor adequadamente sobre seu conteúdo.

Tais lições são totalmente aplicáveis no direito brasileiro, posto que se mostram absolutamente compatíveis com o sistema protetivo pátrio. Os deveres (dirigidos ao fornecedor) de informação e redação contratual de fácil compreensão, aliás, encontram-se positivados nos artigos 46 e $54, \S 3^{\circ}$ do $\mathrm{CDC}$; a regra contra proferentem, de modo semelhante, é prevista no artigo 47 do CDC e no artigo 423 do Código Civil (para os contratos de adesão).

Transportando essas considerações para o âmbito da cláusula que prevê o prazo de tolerância, pode se concluir que sua redação deverá ser clara, com destaque gráfico no instrumento contratual, e deve haver ainda expressa aceitação pelo consumidor. Além disso, as razões autorizadoras do adiamento da data de conclusão das obras devem ser fatos extraordinários, cuja ocorrência escape à previsibilidade do incorporador. Afinal, havendo possibilidade de este antever o evento, deverá fixar suas obrigações contratuais - inclusive o preço e o prazo de entrega do edifício - de acordo com sua previsão.

A causa ensejadora da dilação deve enquadrar-se nos conceitos de caso fortuito ou força maior (revestindo-se também de imprevisibilidade), que, malgrado a inexistência de disposição legal específica, são excludentes da responsabilidade do fornecedor, por cortarem o nexo causal entre sua atuação e o inadimplemento contratual (SANSEVERINO, 2010, p. 316 et seq.). Acontecimentos comuns, corriqueiros, que as regras de experiência da própria profissão indicam que frequentemente ocorrem em incorporações, não podem fundamentar a 
extensão contratual do prazo. O incorporador deverá, antes de lançar seu empreendimento, computá-los no cálculo da data prevista para a entrega do edifício aos adquirentes.

Raciocínio contrário constituiria verdadeiro estímulo à publicidade enganosa e à captação irregular de clientes, práticas vedadas pelos artigos 37 e 67 do CDC. Isso porque, ao elaborar as campanhas publicitárias para divulgar as unidades a serem construídas, o incorporador geralmente indica o prazo de conclusão das obras - o que sem dúvida é um fator que leva o futuro adquirente a interessar-se pelo empreendimento, levando-o à contratação. Admitindo-se o uso indiscriminado da cláusula de tolerância, o incorporador anunciaria um prazo na oferta, valendo-se dele para atrair os consumidores, mas na verdade se vincularia a outro, mais extenso, em virtude da previsão contratual. A permissão irrestrita para a pactuação da referida cláusula configuraria uma ilegítima autorização ao fornecedor para estabelecer, imotivadamente, prazo de entrega diverso do previsto na campanha publicitária. $\mathrm{O}$ consumidor seria, assim, iludido à contratação - ou pelo menos à busca de maiores informações sobre a incorporação, estimulando seu interesse pela compra - por uma informação inverídica.

Consequentemente, o prazo de tolerância deve se limitar às hipóteses de fatos imprevisíveis, caracterizadores de caso fortuito ou força maior, e se restringir temporalmente ao estritamente necessário para recuperar o bom andamento da obra - à semelhança do que se exige nas exemption clauses inglesas (MURDOCH; HUGUES, 2008, p. 152).

Além disso, em geral, o adquirente não terá em seu favor qualquer permissão contratual análoga para os casos em que atrase os pagamentos devidos ao incorporador. A revisão dos encargos do consumidor somente poderá ser feita judicialmente; já o incorporador é beneficiado com a permissão contratual para prolongar seu prazo - sem a necessidade de recorrer ao Poder Judiciário para tanto. Essa autorização, repita-se, não é abstratamente abusiva, já que o contrato de incorporação tem certas dificuldades que a justificam.

Entretanto, verificando-se que a cláusula é desproporcional, estabelecendo dilação exagerada em favor do fornecedor, ou prevendo como autorizadores da prorrogação fatos previsíveis e que não configuram caso fortuito ou força maior, o reconhecimento da nulidade da cláusula se impõe. A hipótese enquadra-se na disposição legal contida no artigo 54, inciso VI e $\S 1^{\circ}$, inciso III do CDC, por criar vantagem demasiada para o fornecedor e, ao mesmo tempo, impor encargo excessivo ao consumidor. A análise de sua abusividade depende das circunstâncias de cada caso, considerando-se também as condições normais de exercício da atividade de incorporação. Nesse contexto, a jurisprudência já formulou alguns critérios para orientar a atuação do intéprete no exame da validade da cláusula contratual em comento. 
O excesso de chuvas em certa época do ano, por exemplo, foi considerado acontecimento previsível e incapaz de estender o prazo $^{38}$. Do mesmo modo, considera-se que a falta de materiais básicos para a construção também não pode ensejar a dilação, já que a compra de quantidade suficiente de insumos é atividade que integra o mínimo de organização exigida do incorporador ${ }^{39}$. Por outro lado, a previsão de período de tolerância de cento e oitenta dias já foi compreendida pelo STJ como aceitável ${ }^{40}$ - entendimento que, aliás, merece ser revisto, pelo exagero do tempo concedido ao fornecedor. As hipóteses elencadas constituem rol meramente exemplificativo, representando apenas tendências jurisprudenciais, e por isso admitem complementação pelo magistrado diante de cada caso. Sempre que se fizerem presentes os elementos do artigo 54 , inciso IV e $\$ 1^{\circ}$, inciso III do CDC, portanto, a declaração de nulidade da cláusula contratual tornar-se-á imprescindível.

\section{A CORREÇÃo MONETÁria dURANTE O PERÍOdO DE ATRASO NA ENTREGA DO IMÓVEL}

O atraso na entrega do imóvel gera, também, consequências quanto à incidência da correção monetária sobre o saldo devedor. Os contratos de aquisição de unidade autônoma na incorporação, em geral, obrigam o adquirente a pagar ao incorporador as prestações relativas à compra à medida que as obras avançam, até sua conclusão e a averbação do habite-se no registro do imóvel. A partir desse momento, é comum a intervenção de uma instituição financeira para mutuar ao consumidor o valor correspondente ao saldo devedor restante ou financiá-lo (CHALHUB, 2010, p. 227).

Na primeira etapa descrita - vale dizer, da celebração do contrato até a conclusão das obras e averbação do habite-se - os contratos celebrados entre consumidor e incorporador disciplinam o método de pagamento das parcelas, com todos os acréscimos legais em caso de mora e índices de reajuste. A quase totalidade desses contratos prevê, como índice de correção monetária, o Índice Nacional do Custo da Construção (INCC), que reflete, além da desvalorização da moeda, o aumento dos custos da atividade construtiva. O fato econômico que autoriza a incidência do INCC, dessa forma, é a variação, no tempo, dos encargos com os quais o incorporador deve arcar para bem conduzir a incorporação.

\footnotetext{
${ }^{38}$ Tribunal de Justiça do Distrito Federal. Ap. Cív. 20130111893342. 2a Turma Recursal dos Juizados Especiais. Rel. Antônio Fernandes da Luz. Julgado em 29/04/2014. DJe de 05/06/2014.

${ }^{39}$ Tribunal de Justiça do Distrito Federal. Ap. Cív. 20130110184440. $2^{\text {a }}$ Turma Recursal dos Juizados Especiais Cíveis. Rel. Aiston Henrique de Sousa. Julgado em 10/12/2013. DJe de 18/12/2013.

${ }^{40}$ Superior Tribunal de Justiça. Ag. Reg. no Ag. REsp. 328.960/RS. T4. Rel. Min. Antonio Carlos Ferreira. Julgado em 13/05/2014. DJe de 28/05/2014.

Revista da Faculdade de Direito - UFPR, Curitiba, vol. 60, n. 1, jan./abr. 2015, p. 163-192.
} 
Justamente por essa peculiaridade, o INCC tende a ter valor mais alto do que o dos outros índices de uso comum nos contratos de financiamento (v.g., o IPCA - Índice Nacional de Preços ao Consumidor Amplo - e o INPC - Índice Nacional de Preços ao Consumidor). É usual, assim, a correção da dívida do consumidor mediante dois índices: o INCC, mais caro, na etapa de construção ${ }^{41}$, e o IPCA, INPC ou outro equivalente, após a conclusão das obras e averbação do habite-se, não raro com intervenção de uma instituição financeira.

O grande problema que se coloca, nos casos de atraso, é que, como os trabalhos de construção não se concluem no prazo, o incorporador continua aplicando o INCC como índice de correção monetária. A justificativa para tanto é o fato de que, como as obras continuam a ocorrer, a correção monetária deve levar em conta a variação dos preços dos insumos, matéria-prima e mão de obra empregados na atividade construtiva ${ }^{42}$.

Caso o edifício tivesse sido entregue no prazo, o preço a ser pago pelo consumidor passaria a ser corrigido por índice que lhe é mais benéfico, afastando o INCC, já que não mais haveria trabalho de construção. A diferença da aplicação de um ou outro índice, em algumas situações, pode chegar a valores significativos. Isso prejudica sobremaneira o consumidor, pois leva ao aumento do preço a ser por ele pago, em virtude de inadimplemento da outra parte, sobre o qual não teve ele, consumidor, qualquer ingerência.

Essa medida constitui verdadeira transferência de responsabilidade pelo atraso ao consumidor. A disciplina da mora repugna a imposição de encargos à parte que não deu causa ao descumprimento, até em virtude do enunciado no artigo 389 do Código Civil ${ }^{43}$ (FARIAS; ROSENVALD, 2012b, p. 546). O único sujeito que deve suportar as consequências da quebra do contrato é o inadimplente. A correção pelo INCC durante o atraso, pois, indevidamente torna o consumidor responsável pelo custeio do encarecimento da construção. $O$ fato supostamente legitimador da incidência do INCC é de responsabilidade do incorporador, já que o tempo de atraso (ao longo do qual os custos produtivos aumentaram) foi por ele provocado. Se suas obrigações contratuais tivessem sido regularmente cumpridas, o uso do INCC seria desnecessário, passando a incidir índice mais benéfico ao consumidor.

A legislação nacional veda tal tipo de estipulação - e há dois fundamentos para se chegar a essa conclusão. Primeiramente, porque o artigo 424 do Código Civil proíbe, nos

\footnotetext{
${ }^{41}$ Como o INCC reflete o aumento nos custos dos materiais de construção, é justificada sua utilização somente durante o período de obras. Afinal, após sua conclusão, o incorporador não precisa mais arcar com a variação no preço dos insumos, matéria-prima e mão de obra, de maneira que se passa a empregar índice de correção monetária que reflita somente a inflação geral do mercado.

${ }^{42}$ Veja-se, permitindo a aplicação do INCC no período de atraso: Tribunal de Justiça do Distrito Federal. Ap. Cív. 20130710059222. 5a Turma Cível. Rel. Des. Gislene Pinheiro. Julgado em 12/03/2014. DJe de 18/03/2014.

${ }_{43}$ Art. 389. Não cumprida a obrigação, responde o devedor por perdas e danos, mais juros e atualização monetária segundo índices oficiais regularmente estabelecidos, e honorários de advogado.

Revista da Faculdade de Direito - UFPR, Curitiba, vol. 60, n. 1, jan./abr. 2015, p. 163-192.
} 
contratos de adesão - que são a virtual totalidade no âmbito da incorporação - a renúncia antecipada a direitos que são da natureza do contrato. A partir da análise da disciplina da mora no Código Civil, percebe-se que as consequências patrimoniais do inadimplemento devem recair, unicamente, sobre o inadimplente, de modo que a parte inocente tem a legítima e óbvia expectativa de não ser responsabilizada pela violação realizada pela outra parte.

Os direitos do contratante inocente à indenização pelos prejuízos e, reflexamente, a não incorrer em ônus adicionais pela mora da contraparte, podem ser tidos como tradicionais da natureza do negócio - de qualquer negócio, em verdade - para os fins do artigo 424 do Código Civil. Pensamento oposto constituiria afronta ao princípio da boa-fé objetiva, orientador tanto do Código Civil (artigo 422) como do CDC (artigo $4^{\mathrm{o}}$, III), por violar a distribuição equânime dos deveres e ônus contratuais e permitir a uma das partes descumprir o contrato voluntária e impunemente (BURTON, 1980, p. 370). A previsão que permite a cobrança do INCC enquanto durarem as obras, mesmo durante o período de atraso, leva o consumidor a antecipadamente renunciar ao direito supracitado, configurando a situação vedada em lei. Dessa forma, a própria legislação civil já seria suficiente para declarar a nulidade da cláusula.

Em segundo lugar, esta deve ter sua abusividade reconhecida por violação do artigo 54 , inciso IV e $\S 1^{\circ}$, inciso III do CDC, pois se enquadra no conceito geral de criação de vantagem excessiva para o fornecedor em detrimento do consumidor. A incidência do INCC, nesses casos, é verdadeira securitização do incorporador contra sua própria negligência, por meio da transmissão, ao consumidor, do gravame de arcar com parte dos custos da mora daquele. As considerações já realizadas nesse texto em relação à abusividade da restituição parcial são totalmente aplicáveis aqui. Além disso, se até mesmo a cláusula que limita a responsabilidade do fornecedor é considerada abusiva (artigo 54, inciso I do CDC), com mais razão também o será a que imponha ao consumidor a obrigação de custear o atraso na entrega do bem.

Outrossim, não se pense que a correção monetária pelo INCC, em tais casos, teria apenas a função de compensar a perda de valor da moeda, de modo que não haveria motivo para afastar a incidência desse índice. Existem outros índices de correção - como o IPCA e o INPC - mais benéficos ao consumidor, que já cumprem essa finalidade. A peculiaridade que caracteriza o INCC é a inclusão, em seu cálculo, da variação dos encargos da atividade construtiva. Considerando que a continuação da obra em período superior ao previsto, no qual ocorre o aumento dos custos produtivos, foi causada exclusivamente pelo incorporador, não 
se pode pretender que o consumidor suporte o referido aumento. A incidência do INCC nessa situação é, portanto, ilegal, assim como é nula e abusiva a cláusula que o permite.

Um dos pedidos recorrentes nas ações que tratam de atrasos na incorporação imobiliária é a eliminação total da incidência de correção monetária durante o período de mora do incorporador. Há, inclusive, precedentes judiciais que acolhem a pretensão do adquirente, levando à existência de um lapso temporal - compreendido entre a data prevista para a conclusão das obras e a data da efetiva entrega do edifício - em que não ocorre qualquer reajuste monetário ${ }^{44}$.

Ainda que, certamente, seja mais vantajoso para o consumidor, tal entendimento não se afigura como o mais correto. No hodierno cenário econômico brasileiro, a moeda inexoravelmente tem seu poder de compra mitigado progressivamente pela inflação, de maneira que a manutenção do equilíbrio entre as obrigações de cada parte depende da correção periódica de seu valor.

Ao eliminar-se a incidência de qualquer índice de correção no período apontado, o consumidor obtém uma diminuição em seu saldo devedor que não ocorreria ainda que o contrato tivesse sido cumprido pelo incorporador exatamente na forma acordada. O sistema protetivo do CDC não visa a favorecer sempre e em todos os casos o consumidor, permitindolhe extrair vantagem financeira mesmo em situações injustificadas. Seu objetivo é proteger a parte vulnerável da relação jurídica, o que deve ser feito dentro dos limites impostos pelo ordenamento jurídico (NUNES, 2012, p. 177).

Realizando-se a correção monetária por outro índice destinado apenas a recompor o valor da moeda, por outro lado, o adquirente paga exatamente aquilo que seria devido em condições normais de execução do contrato, sem prejuízo para qualquer das partes. Afinal, não há fundamento para que o atraso na entrega do imóvel diminua o saldo devedor, o que aconteceria caso se afastasse totalmente a correção monetária. A mora do incorporador tem consequências próprias, como o dever de indenizar o consumidor, mas não deve ter o condão de realizar a referida diminuição - a não ser, é claro, pela compensação entre a indenização devida ao consumidor e o saldo devedor. A solução mais correta, portanto, é manter a

\footnotetext{
${ }^{44}$ Confira-se, por exemplo: Tribunal de Justiça do Estado de São Paulo. Ag. Inst. 20128073320148260000. $3^{\text {a }}$ Câmara de Direito Privado. Rel. Des. Carlos Alberto de Salles. Julgado em 18/02/2014. Publicado em $20 / 02 / 2014$
} 
correção do preço a ser pago mediante outro índice previsto no contrato - como o IPCA ou o INPC - ou fixado pelo juiz, de maneira a preservar o equilíbrio financeiro do negócio ${ }^{45}$.

\section{CONSIDERAÇÕES FINAIS}

A finalidade máxima de todo contrato é seu pleno adimplemento, com a satisfação das obrigações nele contidas e a observância dos deveres anexos derivados dos princípios da boa-fé e da probidade. $\mathrm{O}$ descumprimento contratual representa, pois, situação de crise, e sua disciplina jurídica deve visar ao máximo à proteção da parte inocente e diligente.

$\mathrm{O}$ atraso na incorporação imobiliária não foge a essa lógica. Em virtude de suas peculiaridades e dos interesses extremamente relevantes que envolve - especialmente o uso habitacional do imóvel - justifica-se uma maior tutela da parte vulnerável dessa espécie de relação jurídica: o consumidor. A proteção a este, todavia, não significa a total desconsideração da posição contratual da outra parte, mas sim o equilíbrio entre sujeitos com poder e conhecimentos díspares, por meio da garantia dos direitos legalmente previstos.

O entendimento que deve nortear a interpretação da matéria, objetivando o desestímulo à negligência do incorporador (fornecedor), é que, uma vez configurada a responsabilidade deste pelo atraso, atribui-se-lhe responsabilidade ampla por qualquer prejuízo (material ou moral) que tenha causado ao consumidor. Observa-se que a jurisprudência pátria já vem caminhando na direção de diversas das soluções aqui apontadas, apesar de ainda existir notável divergência entre os Pretórios.

Deve ser garantido ao consumidor, nos casos de atraso, o direito à resolução do contrato, com a restituição integral de todos os valores pagos - o que abrange não somente as parcelas referentes ao preço do imóvel, mas também todas as outras taxas e encargos contratuais. Qualquer cláusula que determine a perda de qualquer desses valores em favor do incorporador (fornecedor) será abusiva e, portanto, nula de pleno direito.

Optando ou não pela resolução contratual, o consumidor lesado em virtude do atraso na entrega do imóvel terá direito à indenização por danos patrimoniais (v.g., danos emergentes e/ou lucros cessantes) e morais, que nestes casos devem ser presumidos.

O contrato pode prever prazo de tolerância para o incorporador, desde que seja pautado em circunstância objetivamente imprevisível ou de efeitos que não poderiam ser antecipadamente calculados. A cláusula em questão deve ainda restringir-se ao mínimo lapso

\footnotetext{
45 Veja-se a seguinte decisão, em que se admitiu a substituição do INCC por índice mais favorável ao consumidor: Tribunal de Justiça do Estado de Minas Gerais. Ap. Cív. 10024121238240001. 14 Câmara Cível. Rel. Des. Marco Aurélio Ferenzini. Julgado em 05/06/2014. Publicado em 18/07/2014.

Revista da Faculdade de Direito - UFPR, Curitiba, vol. 60, n. 1, jan./abr. 2015, p. 163-192.
} 
temporal necessário para promover a regularização no andamento da obra, reputando-se abusiva a prorrogação por período excessivamente extenso.

Por fim, quanto à correção monetária, será inaplicável o INCC durante o período de atraso, por implicar transferência de responsabilidade do incorporador (fornecedor) ao consumidor. A isenção da correção, todavia, não é uma solução juridicamente válida, devendo ser adotado índice de reajuste mais benéfico ao consumidor (v.g., INPC ou IPCA).

\section{REFERÊNCIAS}

AGUIAR JÚNIOR, Ruy Rosado de. Extinção dos contratos. In: FERNANDES, Wanderley. Fundamentos e princípios dos contratos empresariais. 2. ed. São Paulo: Saraiva, 2012.

ALEMANHA. Makler- und Bauträgerverordnung, de 20 de junho de 1974. . Bürgerliches Gesetzbuch, de 18 de agosto de 1896.

ALMEIDA, João Batista de. Manual de direito do consumidor. 5. ed. São Paulo: Saraiva, 2011.

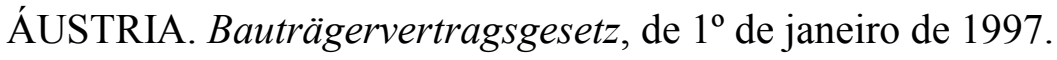

AZEVEDO, Antônio Junqueira de. Negócio jurídico: existência, validade e eficácia. 4. ed. São Paulo: Saraiva, 2010.

BENJAMIN, Antônio Herman de Vasconcellos e; MARQUES, Claudia Lima; BESSA, Leonardo Roscoe. Manual de direito do consumidor. 4. ed. São Paulo : Revista dos Tribunais, 2012.

BERGEL, Jean-Louis. Vente d'immeuble à rénover: contrat, intervenants, régime fiscal. Paris: Lamy, 2010.

BETTI, Emílio. Teoria geral do negócio jurídico. Coimbra: Coimbra, 1970. (t. III).

BOARDMAN, Michelle. Contra proferentem: the allure of ambiguous boilerplate. Michigan Law Review, Ann Arbor, v. 104, 5, p. 1105-1128, fev./mar. 2006.

BRASIL. Constituição da República Federativa do Brasil, de 5 de outubro de 1988.

. Lei Federal $n^{a}$ 4.591, de 16 de dezembro de 1964. Dispõe sobre o condomínio em edificações e as incorporações imobiliárias.

. Lei Federal $n^{\circ}$ 5.869, de 11 de janeiro de 1973. Institui o Código de Processo Civil.

Lei Federal $n^{\circ}$ 8.078, de 11 de novembro de 1990. Dispõe sobre a proteção do consumidor e dá outras providências. 
. Lei Federal $n^{\circ} 8.245$, de 18 de outubro de 1991. Dispõe sobre as locações dos imóveis urbanos e os procedimentos a elas pertinentes.

. Lei Federal $n^{\circ}$ 9.514, de 20 de novembro de 1997. Dispõe sobre o Sistema de Financiamento Imobiliário, institui a alienação fiduciária de coisa imóvel e dá outras providências.

Lei Federal $n^{\circ} 10.406$, de 10 de janeiro de 2002. Institui o Código Civil.

. Lei Federal $n^{o} 10.931$, de 2 de agosto de 2004. Dispõe sobre o patrimônio de afetação de incorporações imobiliárias, Letra de Crédito Imobiliário, Cédula de Crédito Imobiliário, Cédula de Crédito Bancário, altera o Decreto-Lei no 911, de 1 o de outubro de 1969, as Leis no 4.591, de 16 de dezembro de 1964, no 4.728, de 14 de julho de 1965 , e no 10.406 , de 10 de janeiro de 2002, e dá outras providências.

BRITO, Rodrigo Azevedo Toscano de. Incorporação imobiliária à luz do CDC. São Paulo: Saraiva, 2002.

BURTON, SteveBreach of contract and the common law duty to perform in good faith. Harvard Law Review, Cambridge (US), v. 94, 2, p. 369-404, nov./dez. 1980.

CAHALI, Yussef Said. Dano moral. 4. ed. São Paulo: Revista dos Tribunais, 2011.

CAVALIERI FILHO, Sérgio; DIREITO, Carlos Alberto Menezes. Comentários ao novo Código Civil. Rio de Janeiro: Forense, 2004. (v. 13).

CHALHUB, Melhim Namem. Da incorporação imobiliária. 3. ed. Rio de Janeiro: Renovar, 2010.

COBIN, Arthur. Conditions in the law of contract. Yale Law Journal, New Haven, v. 28, 8, p. 739-768, jun./jul. 1919.

COOKER, Robert. Damages for breach of contract. California Law Review, Berkeley, v. 73, 5, p. 1432-1481, set./out. 1985.

DIDIER JÚNIOR, Fredie; BRAGA, Paula Sarno; OLIVEIRA, Rafael. Curso de direito processual civil. 7. ed. Salvador: JusPodvim, 2012. (v. 2).

FARBER, Daniel. Reassessing the economic efficiency of compensatory damages for breach of contract. Virginia Law Review, Charlottesville, v. 66, 8, p. 1443-1484, nov./dez. 1980.

FARIAS, Cristiano Chaves de; ROSENVALD, Nelson. Curso de direito civil: contratos. 2. ed. Salvador: JusPodivm, 2012. (v. 4).

. Curso de direito civil: obrigações. 6. ed. Salvador: JusPodivm, 2012. (v. 2).

FRANÇA. Code Civil Français, de 21 de março de 1804.

GAGLIANO, Pablo Stolze; PAMPLONA FILHO, Rodolfo. Novo curso de direito civil: contratos. 8. ed. São Paulo: Saraiva, 2012. (v. 4, t. I). 
GHEZZI, Leandro Leal. A incorporação imobiliária à luz do Código de Defesa do Consumidor e do Código Civil. 2. ed. São Paulo: Revista dos Tribunais, 2011.

GRZIWOTZ, Herbert. Bauträgervertrag: Vertragliche Gestaltungen zur Risikominimierung des Erwerbers bei mangelnder Bebaubarkeit. Monatsschrift für deutsches Recht, Berlin, v. 68, 8, p. 433-437, mar./abr. 2014.

JAYME, Erik. Identité culturelle et intégration: le droit international privé postmoderne.. Haia: Kluwer, 1995. (Recueil des Cours de l'Académie de Droit International de la Haye, t. 251).

LISBOA, Roberto Senise. Responsabilidade civil nas relações de consumo. 2. ed. São Paulo: Revista dos Tribunais, 2006.

MARINONI, Luiz Guilherme; ARENHART, Sérgio Cruz. Curso de processo civil: processo de conhecimento. 10. ed. São Paulo: Saraiva, 2012. (v. 2).

MARQUES, Cláudia Lima. Contratos no Código de Defesa do Consumidor: o novo regime das relações contratuais. 6. ed. São Paulo: Revista dos Tribunais, 2011.

MICHELlAZZO, Busa Mackenzie. Do dano moral. 4. ed. São Paulo: Lawbook, 2000.

MIRAGEM, Bruno. Curso de direito do consumidor. 2. ed. São Paulo: Revista dos Tribunais, 2010.

MURDOCH, John; HUGHES, Will. Construction contracts: law and management. 4. ed. Abingdon: Taylor \& Francis, 2008.

NUNES, Luis Antonio Rizzato. Curso de direito do consumidor. 7. ed. São Paulo: Saraiva, 2012.

PEREIRA, Caio Mário da Silva. Condomínio e incorporações. 11. ed. Rio de Janeiro: Forense, 2014.

Instituições de direito civil: teoria geral das obrigações. 24. ed. Rio de Janeiro: Forense, 2011. (v. 2).

RAMOS, Alex Humboldt de Souza; ARAÚJO JÚNIOR, Deusdeth Batista de. As cláusulas abusivas mais recorrentes nos contratos imobiliários e os possíveis mecanismos de proteção ao consumidor. In Verbis, Natal, v. 17, 32, p. 61-75, jul./dez. 2012.

SANSEVERINO, Paulo de Tarso Vieira. Responsabilidade civil no Código do Consumidor e a defesa do fornecedor. 3. ed. São Paulo: Saraiva, 2010.

SCAVONE JÚNIOR, Luiz Antonio. Direito imobiliário: teoria e prática. 7. ed. Rio de Janeiro: Forense, 2014.

SILVA, Regina Beatriz Tavares da. Código Civil comentado. 5. ed. São Paulo: Saraiva, 2010. THEODORO JÚNIOR, Humberto. Dano moral. 7. ed. São Paulo: Juarez de Oliveira, 2010. 
WEYTS, Luc. La vente immobilière. Bruxelas: Kluwer, 2002.

WIELE, Philippe Van de. La vente d'immeubles. 2. ed. Bruxelas: De Boeck, 2001.

ZULIANI, Ênio Santarelli. Responsabilidade civil nos contratos de construção, empreitadas e incorporações. In: SILVA, Regina Beatriz Tavares da. Responsabilidade civil e sua repercussão nos tribunais. 2. ed. São Paulo: Saraiva, 2009, p. 239-277.

\title{
THE CONSUMER'S LEGAL PROTECTION IN FACE OF REAL ESTATE DEVELOPER'S DELAY
}

\begin{abstract}
This article deals with the legal consequences of the contractor's delay in delivering the building in a real estate development contract, analyzing the options legally provided to the consumer affected by the delay. The contract of acquisition of an autonomous unit in a real estate development involves, as a rule, supplier and consumer, which attracts the incidence of the protective system established by the Consumer Defense Code. By analyzing the existing regulation, the specialized academic production and courts' precedents, the objective of this work is to show that the logic that should guide such cases of delay is the liability of the contractor in case of harms of any order inflicted upon the consumer, assuring to the latter the autonomy to remain in the contract or to withdraw from it.
\end{abstract}

KEYWORDS: Consumer protection. Delay in the delivery of the building. Real estate development. 